\title{
Studi Jenis Tumbuhan Paku Epifit Pada Kawasan Taman Wisata Alam Baning Sintang
}

\author{
Ria Rosdiana Hutagaol \\ Fakultas Pertanian Universitas Kapuas Sintang \\ Email : riarose.h@gmail.com
}

\begin{abstract}
Abstrak :Tumbuhan paku epifit merupakan salah satu komponen penyusun ekosistem hutan yang memiliki fungsi ekologis dan ekonomis. Fungsi ekologis tumbuhan paku epifit antara lain sebagai habitat berbagai jenis serangga, sedangkan fungsi ekonomisnya adalah sebagai tanaman hias. Penelitian ini dilakukan di Taman Wisata Alam Baning, Sintang. TWA ini merupakan kawasan ekosistem yang khas yaitu hutan alam rawa gambut yang terletak di tengah Kota Sintang-Kalimantan Barat. Penelitian ini bertujuan untuk mengetahui jenis-jenis Paku Epifit pada kawasan Taman Wisata Alam Baning, Sintang.Metode yang digunakan dalam penelitian ini adalah metode jalur berpetak, dimana jalur pengamatan dibuat sebanyak 2 (dua) buah, dengan panjang jalur masing-masing $500 \mathrm{~m}$. Peletakan jalur dilakukan secara purposive sampling selanjutnya dibuat petak pengamatan dengan ukuran $20 \mathrm{~m}$ x $20 \mathrm{~m}$ pada setiap jalur pengamatan, dengan jumlah 25 petak untuk masing-masing jalur penelitian.Hasil penelitian menunjukkan terdapat 8 jenis paku epifit, yaitu Paku Sarang Burung (Asplenium nidus L), Paku Tanduk Rusa ( Platycerium coronarium), Paku Kepala Tupai (Drynaria quercifolia), Paku Tutup (Davallia denticulata (Burm. Fil.) Mett, Paku Miding (Stenochlaena palustris), Paku Sisik Naga (Pyrrosiapiloselloides L), Paku Peldang (Haplopteris ensiformis (Sw.) dan Lephtochilus sp.
\end{abstract}

Kata Kunci : Paku Epifit, Taman Wisata Alam Baning

\section{PENDAHULUAN}

Tumbuhan Paku memiliki manfaat penting dalam komunitas dan struktur hutan hujan tropis serta berperan dalam pendauran hara. Tumbuhan paku juga juga memiliki beberapa peranan penting yaitu dalam pembentukan humus, melindungi tanah dari erosi, menjaga kelembaban tanah dan salah satu tumbuhan pionir atau perintis dalam tahapan awal suksesi ekosistem hutan.

Paku epifit memiliki peran penting dalam ekosistem hutan, namun selama ini kurang mendapat perhatian. Paku epifit secara ekologis memiliki fungsi sebagai pencampur serasah bagi pembentukan hara tanah, produsen dalam rantai makanan, dan habitat bagi beberapa hewan terutama serangga. Selain itu paku epifit juga dapat digunakan sebagai media pembelajaran, obatobatan, bahan kerajinan maupun bahan makanan.

Tawasan Wisata Alam Baning merupakan areal konservasi yang unik karena terletak di tengah Kota Sintang-Kalimantan Barat. Sebelum menjadi taman wisata alam, status kawasan ini adalah hutan lindung. Perubahan tersebut berdasarkan Surat
Keputusan Menteri Kehutanan No. 129/KPTS-II/ 1990 tanggal 24 Maret 1990 tentang penunjukkan Hutan Lindung Baning menjadi Taman Wisata Alam Baning. Hal ini dipertegas lagi dengan Surat Keputusan Menteri Kehutanan dan Perkebunan Nomor : 405/KPTS-II/99 Tanggal 14 Juni 1999 tentang penetapan kawasan Taman Wisata Alam Baning seluas 213 (dua ratus tiga belas) hektar.

TWA Baning merupakan ekosistem hutan rawa gambut yang membuat kawasan ini memiliki sumberdaya alam hayati yang khas, termasuk tumbuhan yang tergolong kedalam jenis pakupakuan (Pteridophyta).

\section{METODE PENELITIAN}

Metode yang digunakan dalam penelitian ini adalah metode jalur berpetak. Jalur pengamatan dibuat sebanyak 2 (dua) buah, dengan panjang jalur masing-masing $500 \mathrm{~m}$. Pada jalur pengamatan selanjutnya dibuat petak pengamatan yang dianggap mewakili daerah penelitian. Petak pengamatan dibuat dengan ukuran $20 \mathrm{~m}$ x $20 \mathrm{~m}$ pada setiap jalur pengamatan, dengan jumlah 25 petak untuk masing-masing jalur penelitian. Pengambilan data

PIPER No. 31 Volume 16 Oktober 2020 


\section{Studi Jenis Tumbuhan Paku Epifit Pada Kawasan Taman Wisata Alam Baning Sintang}

di lapangan dilakukan pada Bulan Juni 2020 selama 1 bulan. Teknik pengumpulan data di lapangan dilakukan dengan menggunakan metode deskriptif eksplorasi. Eksplorasi adalah pelacakan atau penjelajahan untuk mencari, mengumpulkan, dan meneliti spesies paku epifit (Pteridophyta). Jenis paku epifit yang ditemukan kemudian diidentifikasi dan dideskripsikan secara terperinci untuk menggambarkan bentuk dan ciri morfologis dari masing-masing jenis.

\section{HASIL DAN PEMBAHASAN}

\section{Hasil Penelitian}

Hasil penelitian menunjukkan terdapat 8 jenis paku epifit yang tergolong ke dalam 4 famili yaitu Asplenaceae, Polypodiceae, Bleachnaceae, dan Ptridanceae yang terdapat dalam TWA Baning Sintang, seperti pada Tabel 1 dan Gambar 1 berikut ini :

Tabel 1. Nama Jenis Paku Epifit di TWA Baning, Sintang

\begin{tabular}{llll}
\hline No & Nama lokal & Nama Ilmiah & Famili \\
\hline 1 & Paku Sarang Burung & Asplenium nidus L & Aspleniaciae \\
2 & Paku Tanduk Rusa & Platycerium coronarium & Polypodiceae \\
3 & Paku Kepala Tupai & Drynaria quercifolia & Polypodiceae \\
4 & - & Lephtochilus sp. & Polypodiceae \\
5 & Paku Tutup & Davallia denticulata (Burm. Fil.) & Polypodiceae \\
& & Mett & \\
6 & Paku Miding & Stenochlaena palustris & Blechnaceae \\
7 & Paku Sisik Naga & Drymoglossum piloselloides (L) & Polypodiceae \\
8 & Paku Peldang & Haplopteris ensiformis (Sw.) E. H. & Pteridaceae \\
& & Crane &
\end{tabular}

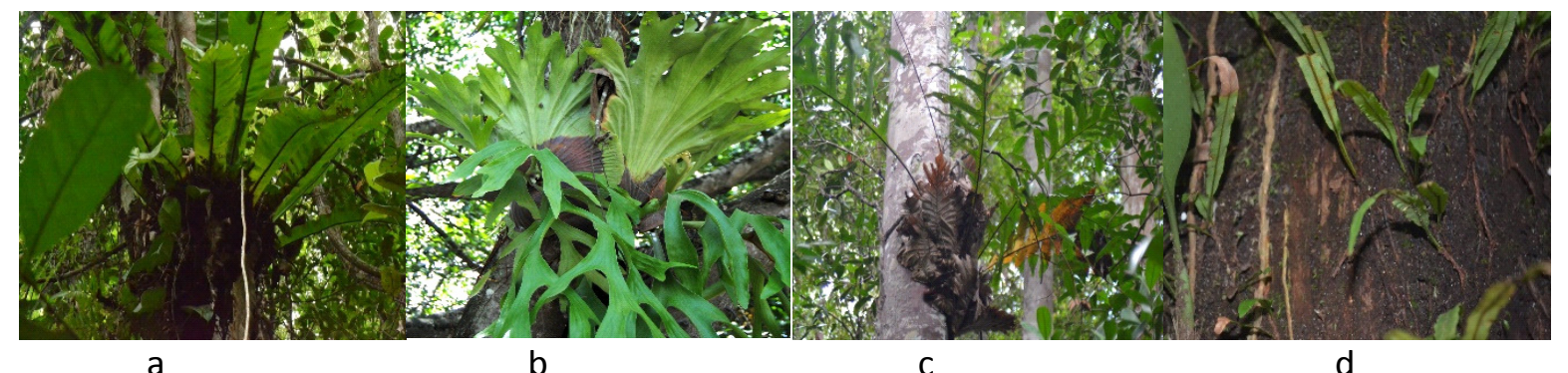

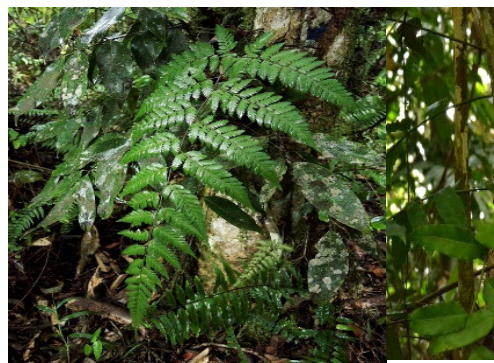

e d

Gambar 1. Jenis-jenis Tumbuhan Paku Epifit di TWA Baning Sintang

Keterangan : a. Asplenium nidus L b. Platycerium bifurcatum c. Drynaria quersifolia

d. Leptochilus sp e. Davallia denticulata (Burm. Fil.) Mett f. Stenochlaena palustris g. Pyrrosiapiloselloides (L) Presl h. Haplopteris ensiformis (Sw.) E. H. Crane 


\section{Pembahasan}

Tumbuhan paku-pakuan (Pteridophyta) adalah tumbuhan yang heterogen ditinjau dari habitat dan cara hidupnya. Tumbuhan paku saat ini berjumlah lebih kurang 10.000 jenis, dengan masing-masing ciri morfologis pada setiap jenisnya (Prastyo dkk, 2015 ; Mahendrati dkk, 2017)

\section{Asplenium nidus L atau Paku Sarang Burung}

Asplenium nidus L termasuk ke dalam famili Aspleniaciae atau dalam bahasa setempat biasa disebut dengan Paku Sarang Burung dapat tumbuh di daerah dataran rendah maupun dataran tinggi. Paku ini menyukai daerah yang lembab dan tidak tahan terhadap cahaya matahari langsung. Di kawasan TWA Baning Sintang, Paku Sarang Burung menempel pada pohon Rengas, Mabang dan Engretak.

\section{Platycerium coronarium}

Platycerium coronariumatau Paku Tanduk Rusa termasuk ke dalam Famili Polypodiaceae. Rimpang paku ini ramping berwarna coklat tua dan tertutup oleh daun-daun penyangga. Daun penyangga pada paku ini tumbuh tegak, berbentuk bulat dan tepi nya berbagi menjari. Daun penyangga Platycerium yang berukuran kecil hanya berbentuk bulat saja dan tepi rata. Tulang daun pada daun penyangga tersusun menjari, dengan tulang cabang tingkat 1 dan tingkat 2 masih terlihat jelas, sedangkan tulang cabang tingkat seterusnya tidak terlihat dengan jelas lagi.

Platycerium coronarium umumnya hidup di pohon-pohon besar di dataran rendah. Pada kawasan TWA Baning jenis ini menempel pada pohon berukuran besar dari jenis Rengas, Mabang dan Engretak. Jenis ini juga diminati masyarakat sebagi tumbuhan hias.

\section{Drynaria quercifolia}

Drynaria quercifolia atau Paku Kepala Tupai termasuk dalam famili Polypodiaceae. Jenis ini mempunyai rimpang yang tebal dan bulat. Rimpang ini ditutupi oleh sisik berwarna coklat tua dan dapat gugur, pada beberapa bagian rimpang terdapat bekas-bekas sisik yang telah gugur. Stipe PIPER No. 31 Volume 16 Oktober 2020 paku ini berbentuk bulat, berwarna coklat dan permukaannya licin. Paku ini memiliki daun penyangga dengan bentuk bulat dan tepi daun yang berlekuk menyirip. Di kawasan TWA Baning, jenis ini ditemukan menempel pada pohon inang dari jenis Rengas,Mabang dan Engertak.

\section{Lephtochilus sp}

Perawakan herba, rimpang terna, jarak antar buku renggang, arah tumbuh memanjat, secara melintang bentuk bulat, bercabang secara dikotom, permukaan rimpang tedapat ramenta berwarna coklat, warna rimpang coklat, daun bentuk lanset, terletak pada sisi dorsal rimpang. Daun megafil daun tunggal, daun bertangkai secara melintang berbentuk bulat, tekstur berdaging, panjang daun bisa mencapai $32 \mathrm{~cm}$, lebar $2.5 \mathrm{~cm}$, bentuk lanset, tepi daun rata, pangkal daun meruncing, permukaan bawah daun penuh dengan ramenta putih. Pertulangan menyirip, peruratan dikotom.

\section{Davallia denticulata (Burm. Fil.) Mett}

Davallia denticulataatau Paku Tutup termasuk ke dalam Famili Davalliaceae. Ciri-ciri dari paku ini ialah memiliki rimpang berbentuk bulat dan ramping. Rimpang terdapat sisik berwarna coklat tua. Stipe berwarna hijau berbentuk bulat dan permukaannya licin. Bangun daun dari paku ini berbentuk delta, dan merupakan tipe daun majemuk menyirip ganda tiga. Daun berwarna hijau tua pada permukaan atas (adaksial) dan hijau muda pada permukaan bawahnya (abaksial).

\section{Pyrrosiapiloselloides (L)}

Pyrrosia piloselloides atau Paku Sisik Naga termasuk dalam Famili Polypodiaceae. Rimpang tumbuhan ini ramping berbentuk bulat dan berwarna coklat. Sisik pada rimpang berwarna gelap pada tengahnya sedangkan tepiannya berwarna lebih pucat. Daun steril berukuran lebih kecil daripada daun fertil. Daun steril ada yang berbentuk bulat atau hampir bulat dan tidak memiliki stipe. Daun fertil memiliki stipe pendek, bentuk daun fertil jorong dengan ujung daun membulat dan pangkal daun runcing. 


\section{Stenochlaena palustris}

Stenochlaena palustris dikenal oleh masyarakat setempat dengan namaPaku Miding. Perawakan parenial dan agak keras, daun menyirip tunggal. Tangkai daun memiliki panjang berukuran 10-20 cm, yang cukup kuat. Daunnya steril, berukuran 2 sampai $3 \mathrm{~cm}$, kuat, mengkilat, gundul, yang muda kerap kali berwarna keungu-unguan; anak daunnya banyak, bertangkai pendek, berbentuk lanset, dengan lebar $1,5 \mathrm{~cm}$, meruncing denan kaki lacip baji atau membulat, kedua sisi tidak sama, diatas kaki begerigi tajam dan halus, urat daun berjarak lebar, anak daun fertil lebarnya 2-5 $\mathrm{mm}$.

\section{Haplopteris ensiformis (Sw.)}

Haplopteris ensiformisatau Paku Peldang termasuk ke dalam famili Pteridaceae. Rimpang paku ini pipih, ramping dan berwarna coklat muda. Daun pada tumbuhan paku ini merupakan daun tunggal dan tidak memiliki stipe, bangun daun seperti garis, pangkal daun meruncing dan ujung daun runcing, tepi daun rata, midrib hanya terlihat pada pangkal daun saja. Adaksial berwarna hijau tua, abaksial berwarna lebih muda

\section{PENUTUP}

\section{KESIMPULAN}

Dari hasil penelitian jenis Paku Epifit yang terdapat pada kawasan Taman Wisata Alam Baning Kabupaten Sintang terdapat 8 jenis Paku Epifit yaituAsplenium nidus $\mathrm{L}$ atau Paku Sarang Burung, Platyceriumcoronariumatau Paku Tanduk Rusa, Drynaria quercifolia atau Paku Kepala Tupai, Davallia denticulata (Burm. Fil.) Mett atau Paku Tutup, Lephtochilus sp, Stenochlaena palustris atau Paku Miding, Pyrrosiapiloselloides (L) atau Paku Sisik Naga dan Haplopteris ensiformis (Sw.) atau Paku Peldang.
Jenis-jenis paku epifit yang ditemukan terdiri dari 4 famili, yaitu dari anggota Aspleniaciae, Polypodiciae, Blechnaceae dan Pteridaceae.

\section{SARAN}

Mengingat keanekarangaman jenis pakupakuan yang tinggi maka perlu penelitian lanjutan baik tentang paku epifit maupun paku terrestrial di kawasan Tawan Wisata Alam Baning, Sintang.

\section{DAFTAR PUSTAKA}

Febriliani, F., Ningsih, S., \& Muslimin, M. 2013. Analisis Vegetasi Habitat Anggrek di Sekitar Danau Tambing Kawasan Taman Nasional Lore Lindu. Jurnal Warta Rimba, 1(1).

Indriyanto. 2008. Ekologi Hutan. Cetakan ke-2. PT Bumi Aksara. Jakarta.

Mahendrati, N., \& Roziaty, E. 2017. Keanekaragaman Tumbuhan Paku Epifit di Kawasan Hutan Pinus Kragilan Kabupaten Magelang Provinsi Jawa Tengah (Doctoral Dissertation, Universitas Muhammadiyah Surakarta).

Prastyo, W. R., Heddy, S., \& Nugroho, A. 2015. Identifikasi Tumbuhan Paku Epifit Pada Batang Tanaman Kelapa Sawit (Elaeis guineensis J.) di lingkungan Universitas Brawijaya. Jurnal Produksi Tanaman, 3(1).

Suraida, T.S. 2013. Keanekaragaman Tumbuhan Paku (Pteridophyta) di Taman Semirata FMIPA Universitas Lampung. IAIN Sulthan Thaha Saifuddin Jambi 